\title{
The Relation Between Hiring Queuers and Emotions - A Pre-Study of
}

\section{Experiment Design}

\author{
Ruo-Yin Liao ${ }^{1, *}$, Chih-Chin Liang ${ }^{2}$ \\ ${ }^{1,2}$ National Formosa University, Taiwan \\ ${ }^{1}$ ryoma0956@gmail.com *; ${ }^{2} \operatorname{lgcwow@gmail.com;~}$ \\ * corresponding author
}

\begin{abstract}
Consumers considering whether or not to queue make their decisions based on queuing size and the expecting waiting time. If a consumer is frustrated because he / she cannot know how long will wait, he / she will quit from a Consumers who are frustrated because they do not know how long they must wait will quit a queue or ask someone for help if the good is worthy to pay more money to own. If a good is worth waiting to purchase, a consumer will chose waiting or buying the privilege to get the good. However, a long wait causes customers to have negative feelings about the queue. Frustration also has a substantial effect on customer loyalty to a good. Therefore, the relationship between perceived waiting time and paying for queuers to buy the good is worth studying. Frustration is a moderating effect that is also worth studying. In the formal study, to make the frustrating emotion, the authors asked all participants to have a contest before they can take the tickets to enter a queue for taking the ticket to a famous concert in Taiwan. The questions used in the contest had different levels of difficulty. However, the difficulty of the questions must be verified before the formal experiment. Therefore, the 60 participants in this pilot study were asked 40 questions in history, mathematics, and Chinese to find the most difficult ten questions and the less difficulty ten questions for the formal test.
\end{abstract}

Keywords: Queuing behavior; negative emotion; perception of waiting time;

\section{Introduction}

A customer who finds a good worth buying must decide whether or not the good is worth queuing to buy it. Of course, joining a queue is not a fun experience. However, the stronger the intention to buy a good, the more possible that a customer joins a queue. Therefore, even a customer who dislikes waiting might be willing to join a queue. For example, when a company sells the iPhone 7 in the end of 2016, there are a lot of buyers waiting in front of the retailing stores. Fans of "Mayday", a famous band from Taiwan, are also willing to join a queue for tickets to their concerts.

A long queuing time may cause customers to have negative feelings about queuing. Consumers may feel that the waiting time is longer when they are in a hurry [27]. Hui \& Tse [23] said that the consumers feel that the schedule is tiring, because they expected nothing about the actual waiting time. Hornik [21], Kellaris \& Kent [28] reported that consumer emotions affect perceived waiting time and that negative emotions increase the perceived waiting time. Waiting is a negative experience because it makes consumers feel unhappy, nervous, and bored when the customers meet the waiting situation again [9] [13] [27] [31] [34] [35] [41] [46] [51] ]. A long wait also causes negative feelings [17] [20].

Customer frustration affects customer loyalty [46]. The loyalty represents the repeat purchase behavior. Restated, customers might skip the wanted product or service and stop their repeating purchase. However, these customers might opt to find others to queue for their purchase of goods. For example, the famous band "Mayday" is with a dramatically attraction to its customers and the customers want to ask others the help of purchase because the long waiting experiences. However, whether feelings of frustration affect customer awareness of waiting time and further hire queuers is still unknown. We hypothesize that frustration has a moderating effect between customer perception of waiting time and the behavior of hiring queuers. Liang [35] has proposed a waiting model mixed with enjoyable situations and further, Liang [35] proposed the model named enjoyable queue model (EQ model) mixed with four cases of waiting situations in Taiwan. This study used the EQ model to analyze the moderating effects of frustration 
on waiting time perceived by the customer and on the decision to hire a queuer. To find the moderating effect of frustration in the formal study, all participants must join a contest before they can take the tickets to enter a queue for taking the tickets to a famous concert in Taiwan. The participants in the contest were asked questions of varying difficulty. However, the difficulty of the questions had to be measured precisely before the formal experiment. Therefore, the 60 participants in this pilot study were asked 40 questions in history, mathematics, and China to find the most difficult ten questions and the less difficulty ten questions for the formal test.

\section{Literature}

\subsection{Queuing phenomenon}

The term "queuing" refers to the phenomenon of waiting in line for a new restaurant, for a new phone that is on sale, or for a department store anniversary sale. Raz et al. [40] and Debo \& Veeraraghavan [11] found that the witness of many consumers in a queue affecting consumers chooses. For example, many customers queuing at the front door of a company might attract other customers to wait in the line [35]. However, the main factors in consumer willingness to queue are the number of people in the queue, the type of queue, the quality of service, marketing strategies, and customer perception of waiting time. Consumers who are willing to queue may still leave if their schedule is tight or if they expect a long waiting time [29]. Katz \& Larson [29] point out the companies tried to reduce the consumer's actual wait time, but consumers respond their perception of waiting time and they often underestimate the actual time.

\subsection{Waiting Time}

The actual waiting time is the standard measurement for objective judgment of time [8]. Consumers are likely to perceive a long waiting time when they have a tight schedule [29]. When consumers wait a long time, the actual time is increased, customer emotion will turn from excitement to uncertainty, which can then cause frustration, anger, or other negative emotions [35].

Seawright \& Sampson [44] found that perceived waiting time is a psychological expectation of waiting time. Perceived waiting time usually differs from actual waiting time [50]. Schmenner [41] reported that the subjective perception waiting time is more important than actual time in the time related studies. Many studies agree that a long waiting time can cause negative economic behaviors and psychological reactions [30] [38] [44] [45]. Jones and Peppiat [28] reported that customers are more willing to wait when the waiting time is known, and the customer felt the perception of waiting time is longer than actual time.

\subsection{Emotion}

Levine, Wyer \& Schwarz [34] divided emotions into fourteen species and then divided the fourteen species of emotion into positive and negative emotions. Watson \& Tellegen [49] found that a person who has positive emotions feels happy or at ease in life. Negative emotions cause a person to feel angry or unhappy. Some studies found that different kinds of emotion could affect customer perception of waiting time [23] [30] [47]. Hornik [23] reported that consumers who have positive feelings perceive that time is passing quickly and tend to underestimate the time that has passed. In contrast, consumers feel negative that will feel the time are slowly, and hope the time are fast. For example, a man or a woman felt easy when he / she walked slowly along the street and it makes him / her feeling that the time is fast and vice versa. Of course, frustration causes a bad mood, which has an unknown effect on the perception of waiting time. Customers may also hire queuers to wait in line for them if they feel] that the waiting is without cost performance. However, the relationships among frustration, customer perception of waiting time, and hiring queuers are rarely studied.

\section{Method}

The concert of a famous band in Taiwan, named "MayDay", always drives crazy fans to join the queue to get a ticket for the concert. Some more crazy fans will be at the queue when the ticket starts sale, and the actual wait time will be longer. If the process of queuing is too long, the fans will feel intolerant and dissatisfied or not, and fans think the waiting time is too long when they feel intolerant and dissatisfied. 
Based on the literature and EQ model, the study must design an experiment for evaluating frustration and survey participants the EQ model. In the formal study, we will propose an experiment for the participants chasing the ticket of the performance of the Mayday concert. A participant must put his / her token to a lottery box as the one of the candidates to win the ticket. Before he / she put the token, the participant must take a series of quizzes. The quiz is designed for building frustration. The quiz contains 40 questions from the easy to the hardest ones. The participants might feel frustration or other emotions. If a participant decided to hire a queuer for the ticket, he / she must raise his hand for help. Therefore, we will help him / her by putting the token into the lottery box. Additionally, to find the moderating effect of frustration, a survey to judge participant emotion is also needed. In this pilot study, all 40 questions items are made and find some participants for the evaluation of the difficulty and the spending time for us to chose the valid 20 question items ( 10 for the hard questions, and ten for the easy questions) for the quiz making the frustration.

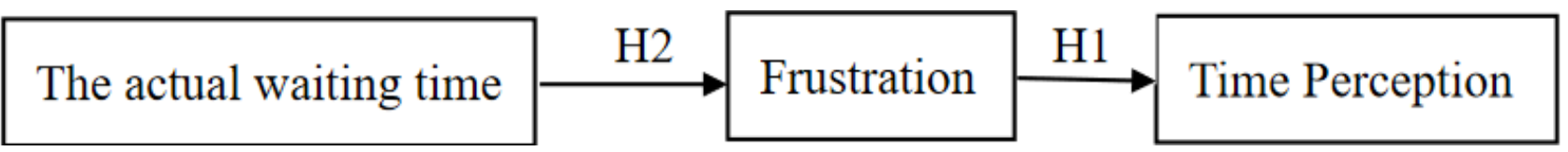

Figure. 1. Research Architecture

Finally, this study must find at least 100 fans of the famous band "MayDay" as the participants. After this pre-test, the study will invite the students who are willing to participate in the formal experiment by posting posters and open recruitment on campus.

\section{Results and Discussion}

According to Table 4.1, there are eleven questions have high correct rate (a1, a3, a5 a, 8, a10, a11, a13, a15 and a26), and twenty questions have high error rate (a2, a9, a12, a14, a16, a17, a19, a21, a24 a34, a37, a38).

Table. 1. Items Analytical Results

\begin{tabular}{|c|c|c|c|c|c|c|c|c|c|c|}
\hline Question & $\mathrm{a} 1$ & $\mathrm{a} 2$ & $\mathrm{a} 3$ & $\mathrm{a} 4$ & $\mathrm{a} 5$ & $\mathrm{a} 6$ & $\mathrm{a} 7$ & $\mathrm{a} 8$ & $\mathrm{a} 9$ & $\mathrm{a} 10$ \\
\hline Number & 57 & 57 & 57 & 57 & 57 & 57 & 57 & 57 & 57 & 57 \\
\hline Correct (\%) & 77.8 & 30.2 & 66.7 & 36.5 & 57.1 & 90.5 & 65.1 & 90.5 & 20.6 & 55.6 \\
\hline Wrong (\%) & 12.7 & 60.3 & 23.8 & 54 & 33.3 & 0 & 25.4 & 0 & 69.8 & 34.9 \\
\hline Question & $\mathrm{a} 11$ & $\mathrm{a} 12$ & $\mathrm{a} 13$ & $\mathrm{a} 14$ & $\mathrm{a} 15$ & $\mathrm{a} 16$ & $\mathrm{a} 17$ & $\mathrm{a} 18$ & $\mathrm{a} 19$ & $\mathrm{a} 20$ \\
\hline Correct (\%) & 90.5 & 30.2 & 73.0 & 11.1 & 69.8 & 14.3 & 27.0 & 49.2 & 39.7 & 47.6 \\
\hline Wrong (\%) & 0 & 60.3 & 17.5 & 79.4 & 20.6 & 76.2 & 63.5 & 41.3 & 50.8 & 42.9 \\
\hline Question & $\mathrm{a} 21$ & $\mathrm{a} 22$ & $\mathrm{a} 23$ & $\mathrm{a} 24$ & $\mathrm{a} 25$ & $\mathrm{a} 26$ & $\mathrm{a} 27$ & $\mathrm{a} 28$ & $\mathrm{a} 29$ & $\mathrm{a} 30$ \\
\hline Correct (\%) & 11.1 & 42.9 & 41.3 & 20.6 & 28.6 & 66.7 & 7.9 & 12.7 & 17.5 & 14.3 \\
\hline Wrong (\%) & 79.4 & 47.6 & 49.2 & 69.8 & 61.9 & 23.8 & 82.5 & 77.8 & 73.0 & 76.2 \\
\hline Question & $\mathrm{a} 31$ & $\mathrm{a} 32$ & $\mathrm{a} 33$ & $\mathrm{a} 34$ & $\mathrm{a} 35$ & $\mathrm{a} 36$ & $\mathrm{a} 37$ & $\mathrm{a} 38$ & $\mathrm{a} 39$ & \multirow{2}{*}{} \\
\hline Correct (\%) & 30.2 & 15.9 & 19.0 & 22.2 & 47.6 & 31.7 & 30.2 & 42.9 & 46.0 & \multirow{2}{*}{} \\
\cline { 1 - 7 } Wrong (\%) & 60.3 & 74.6 & 71.4 & 68.3 & 42.9 & 58.7 & 60.3 & 46.0 & 44.4 & \\
\hline
\end{tabular}

According to Table 4.2, the response time of a question is not over 60 seconds. Additionally, because the data showed the extreme values, some participants may not seriously answer those questions. 
Ruo-Yin Liao \& Chih-Chin Liang / Vol. 3, No. 3, December 2020, pp. 114-120

Table. 2. Analytical Results of Responding Time

\begin{tabular}{|c|c|c|c|c|c|c|c|c|c|}
\hline Question & $\begin{array}{c}\text { Min } \\
\text { (Seconds) }\end{array}$ & $\begin{array}{c}\text { Max } \\
\text { (Seconds) }\end{array}$ & Avg & SD & Question & $\begin{array}{c}\text { Min } \\
\text { (Seconds) }\end{array}$ & $\begin{array}{c}\text { Max } \\
\text { (Seconds) }\end{array}$ & Avg & SD \\
\hline b1 & 0 & 300 & 42.79 & 48.619 & b21 & 1 & 330 & 65.11 & 60.733 \\
\hline b2 & 1 & 120 & 18.61 & 20.659 & b22 & 0 & 270 & 41.60 & 41.418 \\
\hline b3 & 1 & 120 & 19.02 & 21.721 & b23 & 1 & 150 & 32.23 & 25.164 \\
\hline b4 & 0 & 270 & 55.81 & 63.801 & b24 & 0 & 270 & 40.65 & 46.647 \\
\hline b5 & 0 & 270 & 16.86 & 36.699 & b25 & 0 & 150 & 39.00 & 32.808 \\
\hline b6 & 1 & 60 & 16.81 & 13.174 & b26 & 1 & 270 & 25.33 & 37.348 \\
\hline b7 & 0 & 270 & 19.42 & 38.587 & b27 & 0 & 300 & 31.82 & 42.631 \\
\hline b8 & 0 & 40 & 12.09 & 10.458 & b28 & 0 & 180 & 39.35 & 36.780 \\
\hline b9 & 1 & 60 & 12.96 & 13.710 & b29 & 0 & 300 & 47.98 & 59.472 \\
\hline b10 & 0 & 120 & 17.00 & 18.268 & b30 & 0 & 240 & 32.02 & 41.761 \\
\hline b11 & 5 & 330 & 64.04 & 60.418 & b31 & 0 & 200 & 28.37 & 30.093 \\
\hline b12 & 3 & 270 & 55.58 & 51.989 & b32 & 0 & 270 & 26.79 & 38.547 \\
\hline b13 & 0 & 110 & 22.39 & 22.493 & b33 & 0 & 60 & 21.82 & 15.780 \\
\hline b14 & 5 & 120 & 41.04 & 29.539 & b34 & 0 & 180 & 29.44 & 31.390 \\
\hline b15 & 1 & 270 & 42.18 & 49.032 & b36 & 0 & 200 & 26.70 & 35.829 \\
\hline b16 & 0 & 180 & 29.96 & 32.191 & b37 & 0 & 300 & 35.49 & 44.011 \\
\hline b17 & 0 & 300 & 86.16 & 86.020 & b38 & 0 & 275 & 25.98 & 42.745 \\
\hline b18 & 1 & 150 & 35.77 & 33.133 & b39 & 0 & 300 & 30.95 & 42.262 \\
\hline b19 & 1 & 120 & 23.16 & 21.262 & b40 & 0 & 270 & 25.53 & 42.450 \\
\hline b20 & 0 & 172 & 42.19 & 35.457 & & & & & \\
\hline
\end{tabular}

According to Table 4.3.1 to Table 4.3.4, the easy questions are c1, c3, c6, c8 c10, c13, and the difficult questions are c16, c19, c20, c21, c24, c29, c30, c32, c34.

Table. 3. Items Analytical Results

\begin{tabular}{|c|c|c|c|c|c|c|c|c|c|c|}
\hline & c1 & c2 & c3 & c4 & c5 & c6 & c7 & c8 & c9 & $\mathrm{c} 10$ \\
\hline Valid & 57 & 57 & 57 & 57 & 57 & 57 & 57 & 57 & 57 & 57 \\
\hline Average & 1.58 & 1.70 & 1.44 & 2.04 & 1.91 & 1.26 & 2.07 & 1.30 & 1.70 & 1.51 \\
\hline Easy (\%) & 54.0 & 42.9 & 57.1 & 19 & 42.9 & 69.8 & 22.2 & 68.3 & 46 & 49.2 \\
\hline Fair (\%) & 20.6 & 31.7 & 27.0 & 49.2 & 12.7 & 17.5 & 39.7 & 17.5 & 25.4 & 36.5 \\
\hline \multirow[t]{2}{*}{ Difficult (\%) } & 15.9 & 15.9 & 6.3 & 22.2 & 34.9 & 3.2 & 28.6 & 4.8 & 19 & 4.8 \\
\hline & c11 & $\mathrm{c} 12$ & $\mathrm{c} 13$ & $\mathrm{c} 14$ & $\mathrm{c} 15$ & $\mathrm{c} 16$ & $\mathrm{c} 17$ & $\mathrm{c} 18$ & c19 & $\mathrm{c} 20$ \\
\hline Average & 2.11 & 2.02 & 1.42 & 2.04 & 2.04 & 2.51 & 2.88 & 2.30 & 2.30 & 2.61 \\
\hline Easy (\%) & 14.3 & 17.5 & 58.7 & 20.6 & 22.2 & 12.7 & 1.6 & 9.5 & 17.5 & 3.2 \\
\hline Fair $(\%)$ & 52.4 & 54.0 & 25.4 & 46.0 & 42.9 & 19 & 7.9 & 44.4 & 28.6 & 28.6 \\
\hline \multirow[t]{2}{*}{ Difficult (\%) } & 23.8 & 19 & 6.3 & 23.8 & 25.4 & 58.7 & 81.0 & 36.5 & 44.4 & 58.7 \\
\hline & $\mathrm{c} 21$ & c22 & $\mathrm{c} 23$ & c24 & $\mathrm{c} 25$ & c26 & $\mathrm{c} 27$ & c28 & c29 & $\mathrm{c} 30$ \\
\hline Average & 2.61 & 2.12 & 2.35 & 2.79 & 2.37 & 2.19 & 2.39 & 2.26 & 2.47 & 2.61 \\
\hline Easy (\%) & 1.6 & 12.7 & 4.8 & 1.6 & 6.3 & 19 & 12.7 & 7.9 & 7.9 & 6.3 \\
\hline Fair (\%) & 31.7 & 54.0 & 49.2 & 15.9 & 44.4 & 34.9 & 30.2 & 50.8 & $31 . .7$ & 22.2 \\
\hline \multirow[t]{2}{*}{ Difficult (\%) } & 57.1 & 23.8 & 36.5 & 73.0 & 39.7 & 36.5 & 47.6 & 31.7 & 50.8 & 61.9 \\
\hline & $\mathrm{c} 31$ & c32 & c33 & c34 & $\mathrm{c} 35$ & C36 & $\mathrm{c} 37$ & c38 & C39 & \\
\hline Average & 2.44 & 2.53 & 2.11 & 2.44 & 2.12 & 2.33 & 2.39 & 2.32 & 2.26 & \\
\hline Easy (\%) & 7.9 & 6.3 & 17.5 & 11.1 & 17.5 & 3.2 & 7.9 & 14.3 & 14.3 & \\
\hline Fair (\%) & 34.9 & 30.2 & 46.0 & 28.6 & 44.4 & 54.0 & 39.7 & 33.3 & 38.1 & \\
\hline Difficult (\%) & 47.6 & 54.0 & 27 & 50.8 & 28.6 & 33.3 & 42.9 & 42.9 & 38.1 & \\
\hline
\end{tabular}




\section{Conclusion}

The pre-study design the questionnaire for a formal experiment to measure the consumer emotions when they are waiting for putting their token on hand into a lottery box. The study analyzed the designed question items, and the found difficult questions and easy questions will be used in the formal study.

\section{References}

[1] Aftanas, L. I., \& Golocheikine, S. A. (2001). Human anterior and frontal midline theta and lower alpha reflect emotionally positive state and internalized attention: high-resolution EEG investigation of meditation. Neuroscience letters, 310 (1), $57-60$.

[2] Aftanas, L. I., Lotova, N. V., Koshkarov, V. I., \& Popov, S. A. (1998). Non-linear dynamical coupling between different brain areas during evoked emotions: An EEG investigation. Biological Psychology, 48, 121-138.

[3] Aftanas, L. I., Varlamov, A. A., Pavlov, S. V., Makhnev, V. P., \& Reva, N. V. (2001). Affective picture processing: Event-related synchronization within individually defined human theta band in modulated by valence dimension. Neuroscience Letter, 303, 115-118.

[4] Aiken, L. S., West, S. G., \& Reno, R. R. (1991). Multiple regression: Testing and interpreting interactions. Sage.

[5] Anupama, H. S., Cauvery, N. K., \& Lingaraju, G. M. (2012). Brain computer interface and its types-a study. International Journal of Advances in Engineering \& Technology, 3 (2), 739.

[6] Arundell, F., \& Cioffi, J. (2005). Using a simulation strategy: An educator's experience. Nurse Education in Practice, 5 (5), 296-301.

[7] Baker, J., \& Cameron, M. (1996). The effects of the service environment on affect and consumer perception of waiting time: An integrative review and research propositions. Journal of the Academy of Marketing Science, 24 (4), 338-349.

[8] Bielen, B., \& Demoulin, N. (2007). Waiting Time Influence on Satisfaction-Loyalty Relationship in Services. Managing Service Quality, 17 (2), 174-193.

[9] Carmon, Z., Shanthikumar, J. G., \& Carmon, T. F. (1995). A Psychological 98 Perspective on Service Segmentation Models: The Significance of Accounting for Consumers' Perceptions of Waiting and Service. Management Science, 41 (11), 1806-1815.

[10] Davidson, R. J. (1992). Anterior cerebral asymmetry and the nature of emotion. Brain and Cognition, 20, 125-151.

[11] Debo, L., \& Veeraraghavan, S. (2009). Joining longer queues: Information externalities in queue choice, Manufacturing \& Service Operations Management 11 (4), 543-562.

[12] Dimitrov, D. M., \& Rumrill Jr, P. D. (2003). Pretest-posttest designs and measurement of change. Work, 20 (2), 159-165.

[13] Dube-Rioux, L., Schmitt, B. H., \& Leclerc, F. (1988). Consumer's Reactions to Waiting: When Delays Affect the Perception of Service Quality. in NA -Advances in Consumer Research Volume 16, eds. Thomas K. Srull, Provo, UT: Association for Consumer Research, 59-63.

[14]Engel, J. F., Kollat, D. T., \& Blackwell, R. D. Consumer Behavior. (1973). New York: Holt, Rinehart, and Winston.

[15]Farwell, L. A., Richardson, D. C., \& Richardson, G. M. (2013). Brain fingerprinting field studies comparing the P300-MERMER and P300 brainwave responses in the detection of concealed information. Cognitive neurodynamics, 7 (4), 263-299.

[16] Fitzsimons, G. J. (2008). Death to dichotomizing. Journal of Consumer Research, 35 (1), 5-8.

[17]Folkes, V. S., Koletsky, S., \& Graham, J. L. (1987). A field study of causal inferences and consumer reaction: the view from the airport. Journal of consumer research, 13 (4), 534-539.

[18] Gazzaniga, M. S., Ivry, R. B., \& Mangun, G. R. (2002). The methods of cognitive neuroscience. Cognitive Neuroscience: The biology of mind, 2, 96-147.

[19] Goldenberg, J., Libai, B., \& Muller, E. (2001). Talk of the network: A complex systems look at the underlying process of word-of-mouth. Marketing letters, 12 (3), 211-223.

[20] Ginkel, A., \& Schöbel, A. (2007). To wait or not to wait? The bicriteriadelay management problem in public transportation. Transportation Science, 41 (4), 527-538.

[21] Montoya-Weiss, M. M., Voss, G. B., \& Grewal, D. (2003). Determinants of online channel use and overall satisfaction with a relational, multichannel service provider. Journal of the Academy of Marketing Science, 31 (4), 448-458. 
Ruo-Yin Liao \& Chih-Chin Liang / Vol. 3, No. 3, December 2020, pp. 114-120

[22] Hayes, A. F. (2013). Introduction to mediation, moderation, and conditional process analysis: A regression-based approach. Guilford Press.

[23] Hornik, J. (1992). Time Estimation and Orientation Mediated by Transient Mood, Journal of Socio-Economics, 21 (3), 209-227.

[24] Huck, S. W., \& Cormier, W. H. (1996). Principles of research design. Reading statistics and research, 578-622.

[25] Hui, M. K. \& Tse, D. K. (1996), What to Tell Consumers in Waits of Different Lengths: An Integrative Model of Service Evaluation, Journal of Marketing, 60 (2), 81-90.

[26] Isen, A. M. (1984). Toward Understanding the Role of Affect in Cognition. in Handbook of Social Cognition, R. S. Wyer and T. K. Srull, ed. Hillsdale, NJ: Erlbaum, 179-236.

[27] Johnstone, S. J., Blackman, R., \& Bruggemann, J. M. (2012), EEG from a single-channel dry-sensor recording device. Clinical EEG and neuroscience, 43 (2), pp. 112-120.

[28] Jones, P., \& Peppiatt, E. (1996). Managing perceptions of waiting times in service queues. International Journal of Service Industry Management, 7 (5), 47-61.

[29] Katz, K. L., Larson, B. M., \& Larson, R. C. (1991). Prescription for the Waiting-in-Line Blues: Entertain, Enlighten, and Engage. Sloan Management Review, 32 (Winter), 44-53.

[30] Kellaris, J. J., \& Kent, R. J. (1992). The influence of music on consumers' temporal perceptions: Dose time fly when you're having fun? Journal of Consumer Psychology, 1 (4), 365-376.

[31] Kumar, P., Kalwani, M. U., \& Dada, M. (1997). The impact of waiting time guarantees on customers' waiting experiences, Marketing Science, 16 (4), 295-314.

[32] Kush, K., \& Cochran, L. (1993). Enhancing a sense of agency through career planning. Journal of Counseling Psychology, $40(4), 434$.

[33] Larson, R. C. (1987). Perspectives on Queues: Social Justice and the Psychology of Queueing. Operations Research, 35 (6), 895-905.

[34] Levine, S. R., Wyer, R. S., \& Schwarz, N. (1994). Are You What You Feel? The Affective and Cognitive Determinants of Self-judgments. Journal of Social sychology, 24 (1), 63-77.

[35] Liang, C. C. (2016). Queuing Management and Improving Customer Experience: Empirical Evidence regarding Enjoyable Queues. Journal of Consumer 30 Marketing (In Press).

[36] Maister, D. H. (1985). The Psychology of Waiting Lines, in The Service Encounter: Managing Employee Customer Interaction in Service Businesses, J. A. Czepiel, M. R. Solomon, and C. F. Surprenant, ed. Lexington, MA: Lexington Books, 113-123.

[37] Meyer, T. (1994). Subjective Importance of Goal and Reactions to Waiting in Line. The Journal of Social Psychology, 134 (6), 819-827.

[38] Mishalani, R. G., McCord M. M., \& Wirtz, J. (2006). Passenger Wait Time Perceptions at Bus Stops: Empirical Results and Impact on Real-Time Evaluating. Journal of Public Transportation, 9 (2), 89-106.

[39] Murray, D. M. (1998). Design and analysis of group-randomized trials, 29. Oxford University Press, USA.

[40]Raz, O. \& Ert, E. (2008). Size Counts: The Effect of Queue Length on Choice between Similar Restaurants. Advances in Consumer Research, 35, 803-804.

[41] Schmenner, R. W. (1995). Service operations management. Englewood Cliffss. New Jessy: Prentice-Hall.

[42] Soremekun, O. A., Takayesu, J. K., \& Bohan, S. J. (2011). Framework for analyzing wait times and other factors that impact patient satisfaction in the emergency department. The Journal of emergency medicine, 41 (6), 686-692.

[43] Scotland, R. (1991). Customer Service: A Waiting Game. Marketing, 1-3.

[44] Seawright, K. K., \& Sampson, E. S. (2007). A Video Method for Empirically Studying Wait-perception Bias. Journal of Operations Management, 25 (5), 1055-1066.

[45] Sweeney, J., \& Swait, J. (2008). The Effect of Brand Credibility on Customer Loyalty. Journal of Retailing and Consumer Services, 15, 179-193.

[46] Stauss, B., Schmidt, M., \& Schoeler, A. (2005). Customer frustration in loyalty programs. International Journal of Service Industry Management, 16 (3), 229-252.

[47] Taylor, S. (1994). Waiting for Service: The Relationship Between Delays and Evaluations of Service. Journal of Marketing, 58 (2), 56-69. 
[48] Thompson, D. A., Yarnold, P. R., Adams, S. L., \& Spacone, A. B. (1996). How accurate are waiting time perceptions of patients in the emergency department? Annals of emergency medicine, 28 (6), 652-656.

[49] Watson, D. \& Tellegen, A. (1985). Toward a Consensual Structure of Mood. Psychological Bulletin, 98 (2), $219-235$.

[50] Wu, X., Levinson, D. M., \& Liu, H. X. (2009). Perception of waiting time at signalized intersections. Transportation Research Record, 2135, 52-59.

[51]Zachariah, R., Fitzgerald, M., Massaquoi, M., Pasulani, O., Arnould, L., Makombe, S., \& Harries, A. D. (2006). Risk factors for high early mortality in patients on antiretroviral treatment in a rural district of Malawi. Aids, 20 (18), $2355-2360$.

[52]Zhou, R. \& Soman, D. (2003). Looking Back: Exploring the Psychology of Queuing and the Effect of the Number of People Behind. Journal of Consumer Research, 29 (4), 517-530. 